\title{
Rancang Bangun Alat Pengamanan Rumah Berbasis Sensor Dan "Panic Button" Sebagai Alarm Keadaan Darurat Di Kompleks RT/RW Menggunakan Nodemcu Esp8266
}

\author{
Haidar Yusuf Al Hambra \\ Fakultas MIPA, Program Studi D3 Teknik Informatika \\ Universitas Sebelas Maret \\ Email: iyus22@student.uns.ac.id
}

Ovide Decroly Wisnu Ardhi, Fendi Aji Purnomo, Nanang Maulana Yoeseph

Fakultas MIPA, Program Studi D3 Teknik Informatika

Universitas Sebelas Maret

Email: ovide@staff.uns.ac.id, fendi_aji@staff.uns.ac.id, nanang.my@staff.uns.ac.id

Info Artikel

\section{Kata Kunci :}

IoT, MQTT, NodeMCU ESP8266,

Keamanan Rumah, Panic Button

\section{Keywords :}

IoT, MQTT, NodeMCU ESP8266,

Home Security, Panic Button

\section{Tanggal Artikel}

Dikirim : 8 Mei 2019

Direvisi : 11 Mei 2019

Diterima : 30 Mei 2019

\section{Abstrak}

Rumah merupakan salah satu kebutuhan dasar manusia setelah sandang dan pangan yang berfungsi sebagai tempat pelindung dan pengaman manusia dari pengaruh dan gangguan alam/cuaca maupun makhluk lain. Di saat jam-jam kerja dapat dipastikan bahwa pasti banyak rumah kosong ditinggal pergi penghuninya. Terlebih lagi untuk musim liburan, seperti perayaan hari raya dan tahun baru. Rumah kosong tersebut menjadi sasaran empuk para pencuri, terutama rumah tanpa sistem keamanan yang memadai. Metode penelitian ini menggunakan alat pengamanan rumah berbasis sensor dan "Panic Button" untuk memantau keadaan di rumah dengan bantuan aplikasi android yang sudah saling terhubung. Hasil penelitian telah berhasil dilakukan pembuatan aplikasi android dan alat pengamanan rumah yang menggunakan board NodeMCU ESP8266 sebagai pusat kontrol dan menerapan konsep Internet of Things (I0T). Alat dan aplikasi android telah diimplementasikan dan dapat berjalan dengan baik

\section{Abstarct}

Home is one of the basic human needs after clothing and food which functions as a place of protection and human safety from the influence and disturbance of nature / weather and other creatures. During working hours, it can be ascertained that many residents will leave empty houses. What's more for the holiday season, such as celebrations for holidays and new years. This empty house is an easy target for thieves, especially houses without an adequate security system. This research method uses a sensor-based home security tool and "Panic Button" to monitor the situation at home with the help of an android application that is interconnected. The results of the study have been successfully made the making of android applications and home security tools that use the ESP8266 NodeMCU board as a control center and apply the Internet of Things (IoT) concept. Android tools and applications have been implemented and can run well 


\section{PENDAHULUAN}

Rumah merupakan salah satu kebutuhan dasar manusia setelah sandang dan pangan yang berfungsi sebagai tempat pelindung dan pengaman manusia dari pengaruh dan gangguan alam/cuaca maupun makhluk lain. Rumah beserta lingkungannya merupakan pusat kegiatan keluarga, pendidikan, pembentukan kepribadian dan nilai budaya suatu komunitas. Oleh karena itu, rumah harus selalu berada dalam keadaan sehat, nyaman dan aman. Namun, dari aktivitas yang dilakukan seharian, hampir sebagian besar dilakukan diluar rumah. Hal ini terjadi di setiap kota-kota besar. Oleh karena itu, untuk jam-jam kerja dapat dipastikan bahwa pasti banyak rumah kosong ditinggal pergi penghuninya. Terlebih lagi untuk musim liburan, seperti perayaan hari raya dan tahun baru. Rumah kosong tersebut menjadi sasaran empuk para pencuri, terutama rumah tanpa sistem keamanan yang memadai. Banyak modus yang dilakukan para pencuri untuk melaksanakan aksinya. Mulai dari mengetuk pintu rumah, pura-pura bertanya alamat, pura-pura menjadi petugas, bahkan sampai berani membobol pintu atau jendela rumah. Dari sekian banyak modus, yang paling sering dijumpai yaitu dengan cara membobol pintu atau jendela dengan paksa [4]. Apabila hal ini sudah terjadi, pemilik rumah tidak bisa secara langsung menyalahkan tetangga, warga sekitar maupun perangkat desa, dikarenakan tidak dketahuinya alarm/pemberitahuan di lingkungan sekitar. Terjadi sebanyak 335.652 kasus kejahatan pada tahun 2017 dan dari setiap 100.000 orang, 129 diantaranya terkena tindak kejahatan [5]. Oleh karena itu dibutuhkan suatu alat yang berfungsi sebagai pengamanan rumah otomatis dan tombol darurat yang dapat memberi peringatan akan adanya bahaya ke warga sekitar. Sehingga warga sekitar bisa mengetahui jika ada kejadian yang membahayakan/darurat. Dengan demikian warga dapat mengantisipasi maupun cepat tanggap terhadap kejadian yang ada. Pengembangan aplikasi panic button telah dikembangkan oleh beberapa peneliti diantaranya berbasis Arduino, GSM dan GPS [nivedita] [1], esp8266, Arduino dan GPS [awodayi] [2] dan voice recognition sebagai panic button yang menggunakan smartphone [3][Febriasyah]. Dalam penelitian ini akan dikembangkan panic button yang dilengkapi dengan sensor alarm untuk kejadian lain seperti pencurian.

\section{METODE PENELITIAN}

Penelitian ini mengembangkan sistem yang terintegrasi menggunakan konsep loT yang menghubungkan antara alat pengamanan rumah, aplikasi android, dan sistem informasi monitoring. Untuk proses bisnis dari sistem ini dapat dilihat pada Gambar 1 dan Gambar 2.

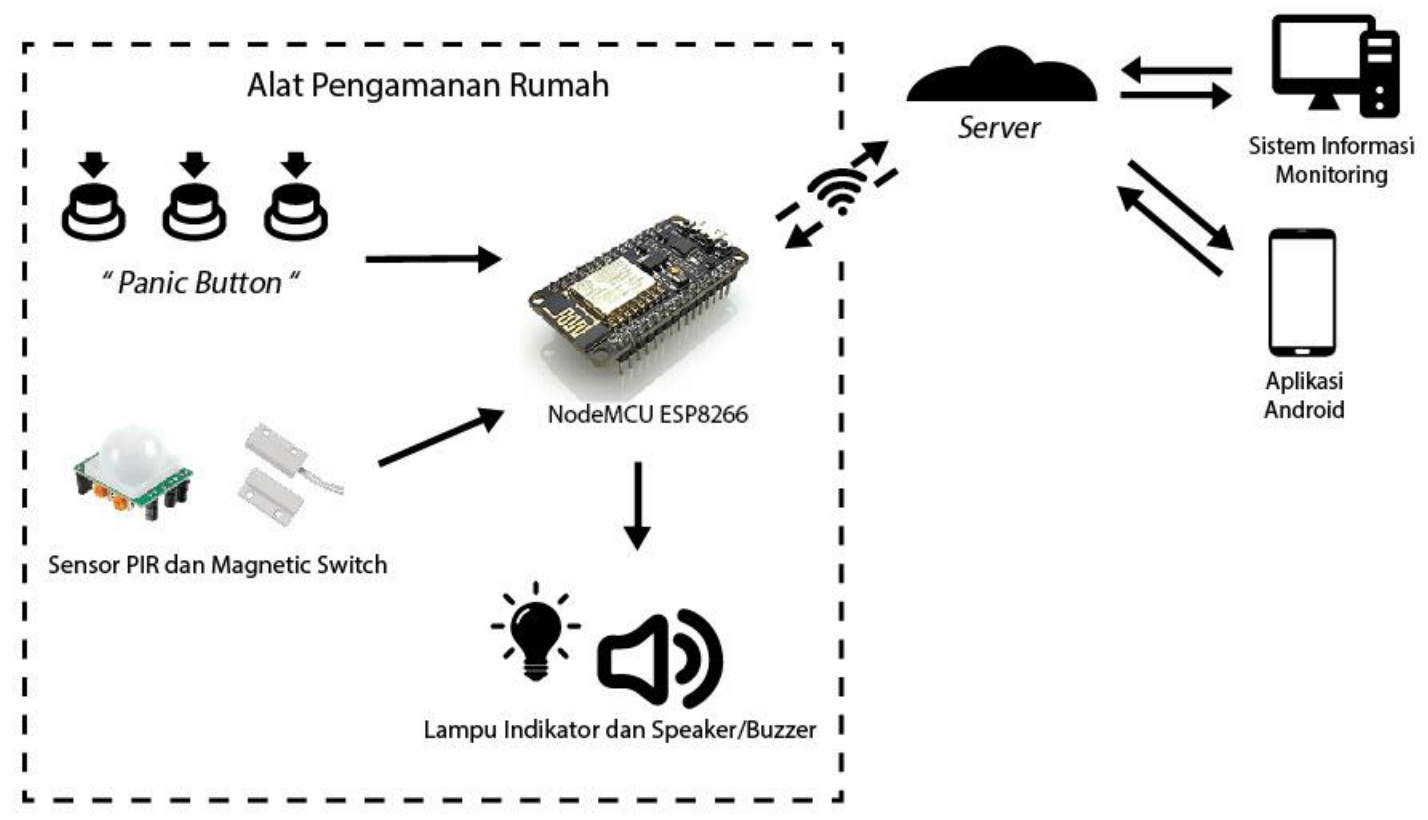

Gambar 1 Alur Kerja Alat

Pada Gambar 1 menjelaskan bahwa pada alat pengamanan rumah terdapat dua buah sensor dan tiga tombol "panic button". Apabila sensor mendeteksi atau "panic button" ditekan maka secara otomatis data yang terdeteksi oleh sensor atau tombol akan dikirimkan ke server dan selanjutnya dapat dilihat pada sistem informasi dan aplikasi android. 


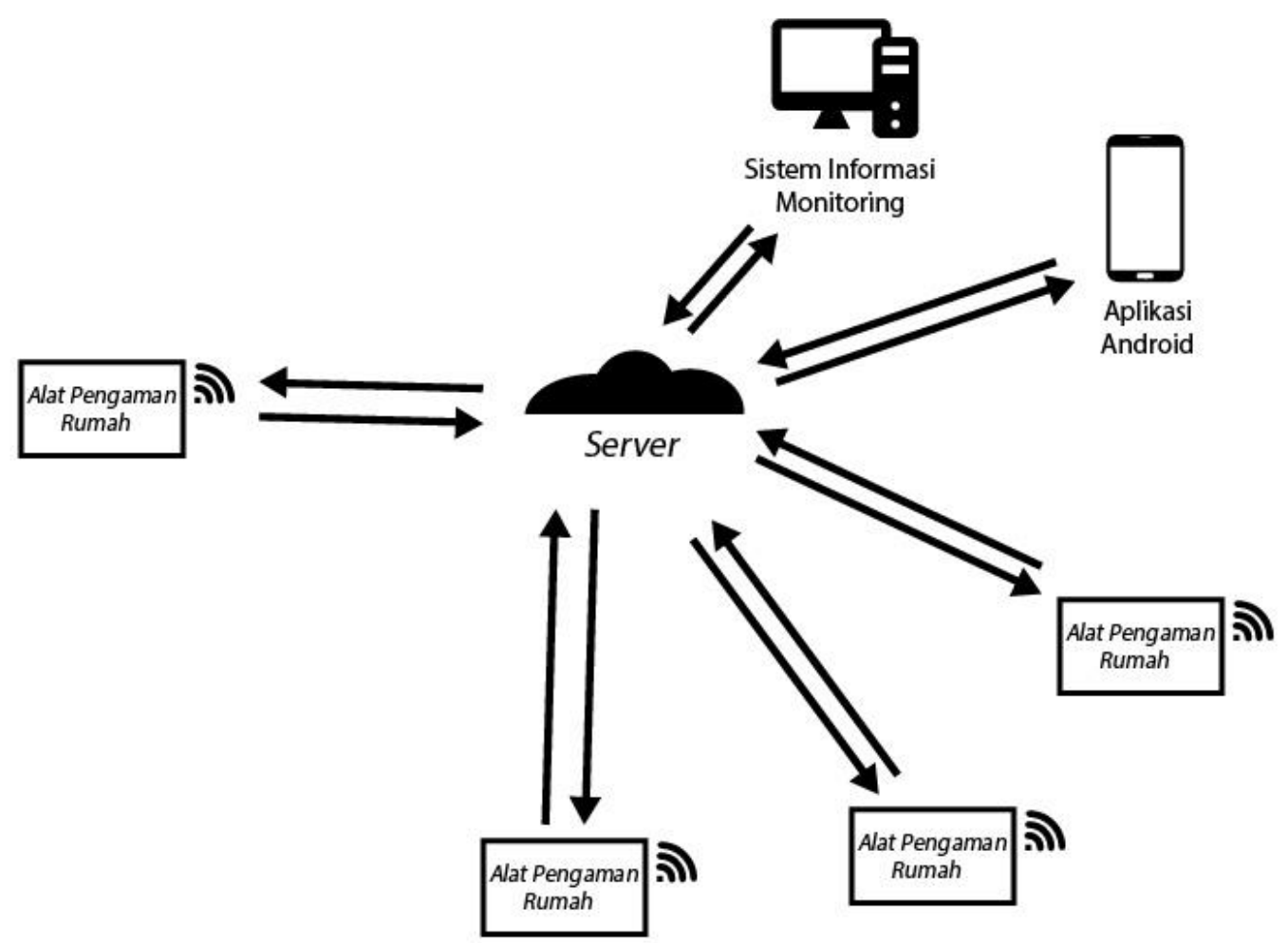

Gambar 2. Alur Kerja Sistem

Pada Gambar 2 menjelaskan bahwa antar alat pengamanan rumah dapat saling mengirimkan dan menerima data. Yang mana apabila salah satu alat mendeteksi melalui sensor atau tombol, maka alat lain yang berada dalam area yang sama akan berbunyi. lunak.

Perancangan sistem ini terdiri dari 2 tahap yaitu tahap perancangan perangkat keras dan tahap perancangan perangkat

\subsection{Perancangan Perangkat Keras}

Pada perangkat keras utama terdiri dari NodeMCU ESP8266 sebagai mikrokontroller, sensor PIR, Reed Switch, Switch Button, LED dan Buzzer. NodeMCU merupakan sebuah open source platform loT dan pengembangan kit yang menggunakan bahasa pemrograman Lua untuk membantu dalam membuat prototype produk loT atau bisa dengan memakai sketch dengan adruino IDE. Pengembangan kit ini didasarkan pada modul ESP8266, yang mengintegrasikan GPIO, PWM (Pulse Width Modulation), IIC, 1-Wire dan ADC (Analog to Digital Converter) semua dalam satu board. Board ini sudah dilengkapi dengan fitur WiFi dan Firmwarenya yang bersifat opensource [6]. Sensor PIR adalah sebuah sensor yang menangkap pancaran sinyal inframerah yang dikeluarkan oleh tubuh manusia maupun hewan. Dikatakan PIR (Passive Infrared Receiver) karena sensor ini hanya mengenali lingkungan tanpa adanya energi yang harus dipancarkan. PIR merupakan kombinasi sebuah kristal pyroelectric, filter dan lensa Fresnel [7]. Saklar magnetic (reed switch) merupakan saklar yang dapat merespon medan magnet yang berada disekitarnya. Magnetic switch ini seperti halnya sensor limit switch yang diberikan tambahan plat logam yang dapat merespon adanya magnet [8]. Kemudian semua dihubungkan pada mikrokontroller NodeMCU ESP8266 sebagai penghubung ke server melalui koneksi internet. Rangkaian perangkat keras dapat dilihat pada Gambar 3. 


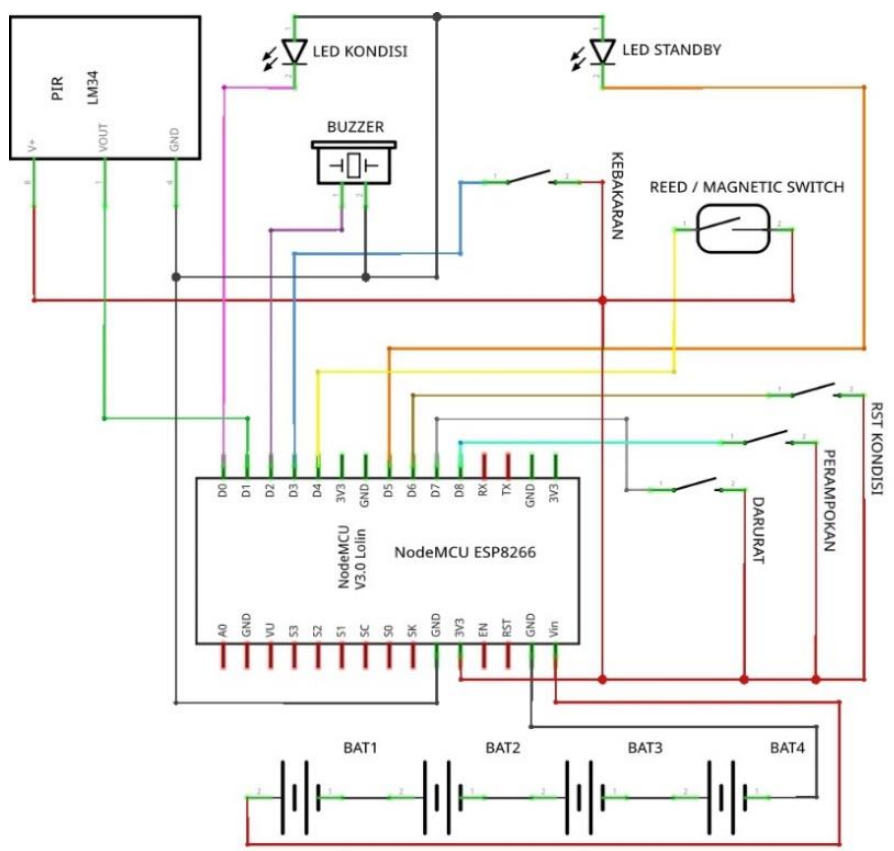

Gambar 3. Skematik rangkaian alat

\subsection{Perancangan Perangkat Lunak}

Perangkat lunak di sini merupakan aplikasi android. Aplikasi dirancang untuk dapat mengirim dan menerima data dari alat (perangkat keras). Aplikasi ini juga memiliki fitur untuk menghidupkan atau mematikan sensor pada alat. Agar dapat digunakan, aplikasi harus terkoneksi dengan internet. Flowchart aplikasi yaitu flowchart user login dapat dilihat pada Gambar 4. Flowchart menghidupkan/mematikan sensor dapat dilihat pada Gambar 5. Flowchart melihat riwayat (history) dapat dilihat pada Gambar 6. Flowchart cek kondisi rumah dapat dilihat pada Gambar 7. Flowchart konfirmasi keadaan aman dapat dilihat pada Gambar 8. Flowchart melihat lokasi kejadian (petugas) dapat dilihat pada Gambar 9.

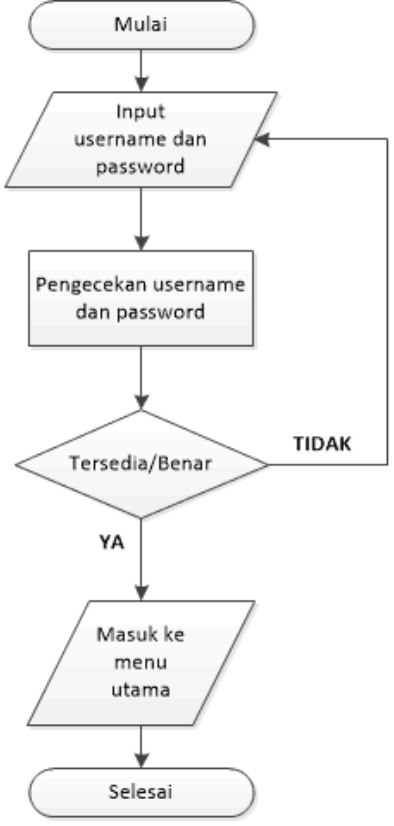

Gambar 4. Flowchart user melakukan login ke aplikasi

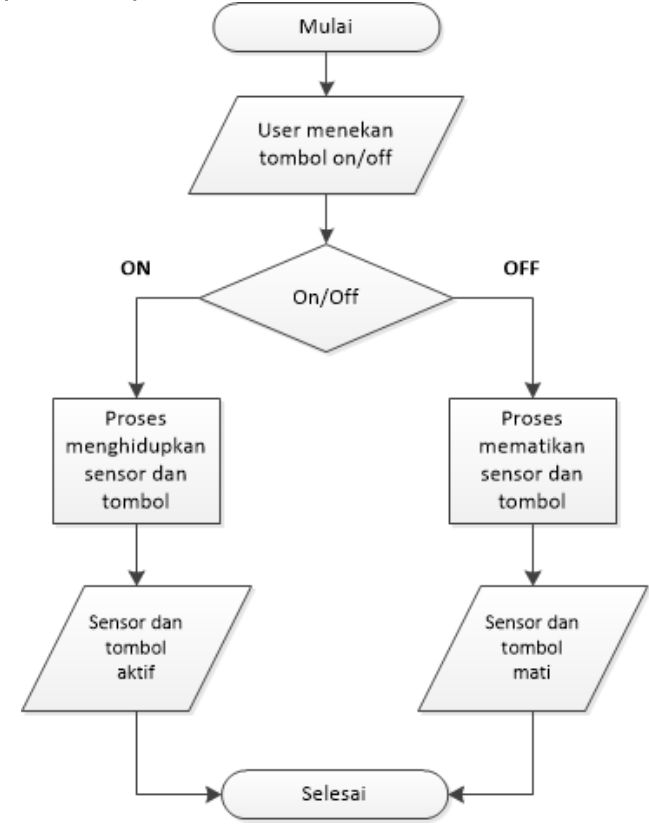

Gambar 5. Flowchart user dapat menghidupkan/mematikan sensor dan tombol 


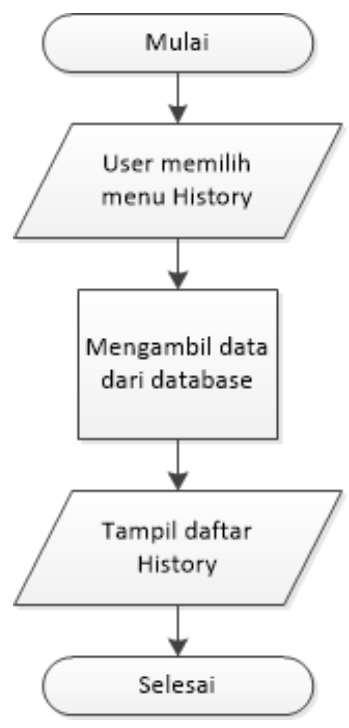

Gambar 6. Flowchart user dapat melihat riwayat

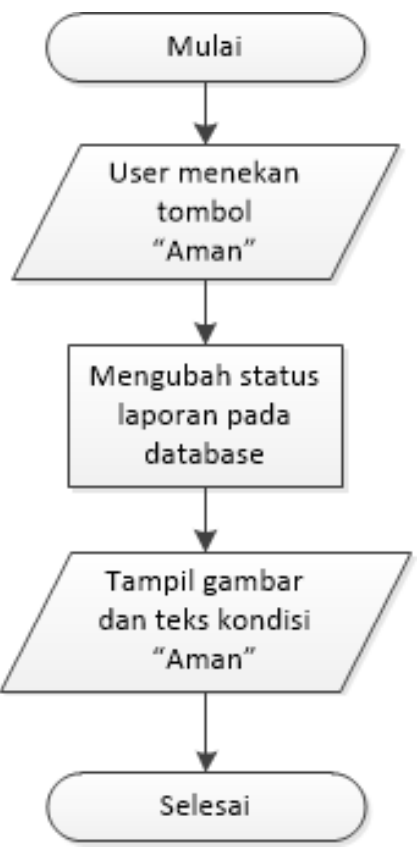

Gambar 8. Flowchart user dapat mengkonfirmasi keadaan aman

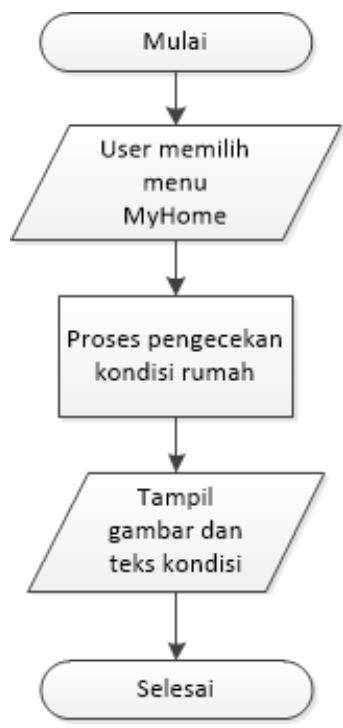

Gambar 7. Flowchart user dapat mengecek kondisi rumah

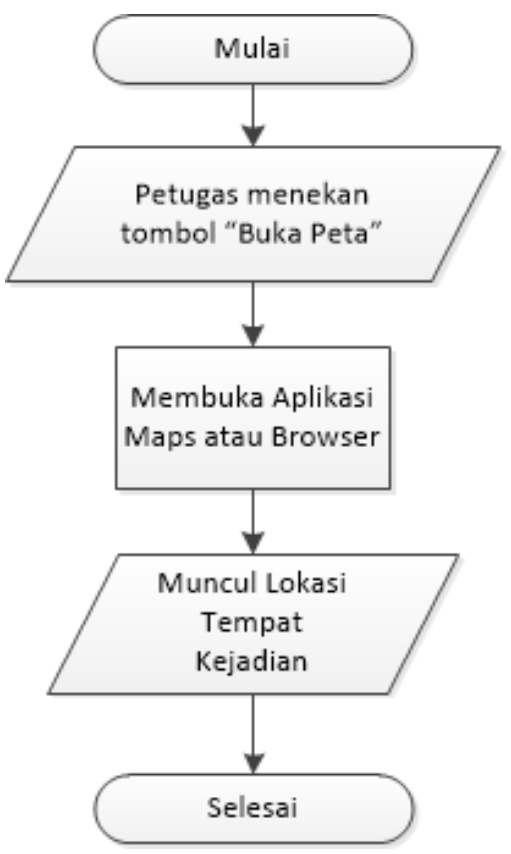

Gambar 9. Flowchart petugas dapat melihat lokasi kejadian

\section{HASIL DAN PEMBAHASAN}

\subsection{Implementasi Perangkat Keras (Alat)}

Pada implementasi perangkat keras digunakan board NodeMCU ESP8266 pusat kontrol, sensor PIR, magnetic switch, tombol (switch button), buzzer, LED dan kabel jumper. Sumber daya yang digunakan yaitu baterai alkaline AA sebanyak 4 buah. Perangkat keras yang sudah dirangkai dan siap dijalankan dapat dilihat pada Gambar 10. LED biru pada Gambar menyala berkedip menandakan alat dalam posisi menyala dan sudah terhubung dengan wifi (kondisi standby). 


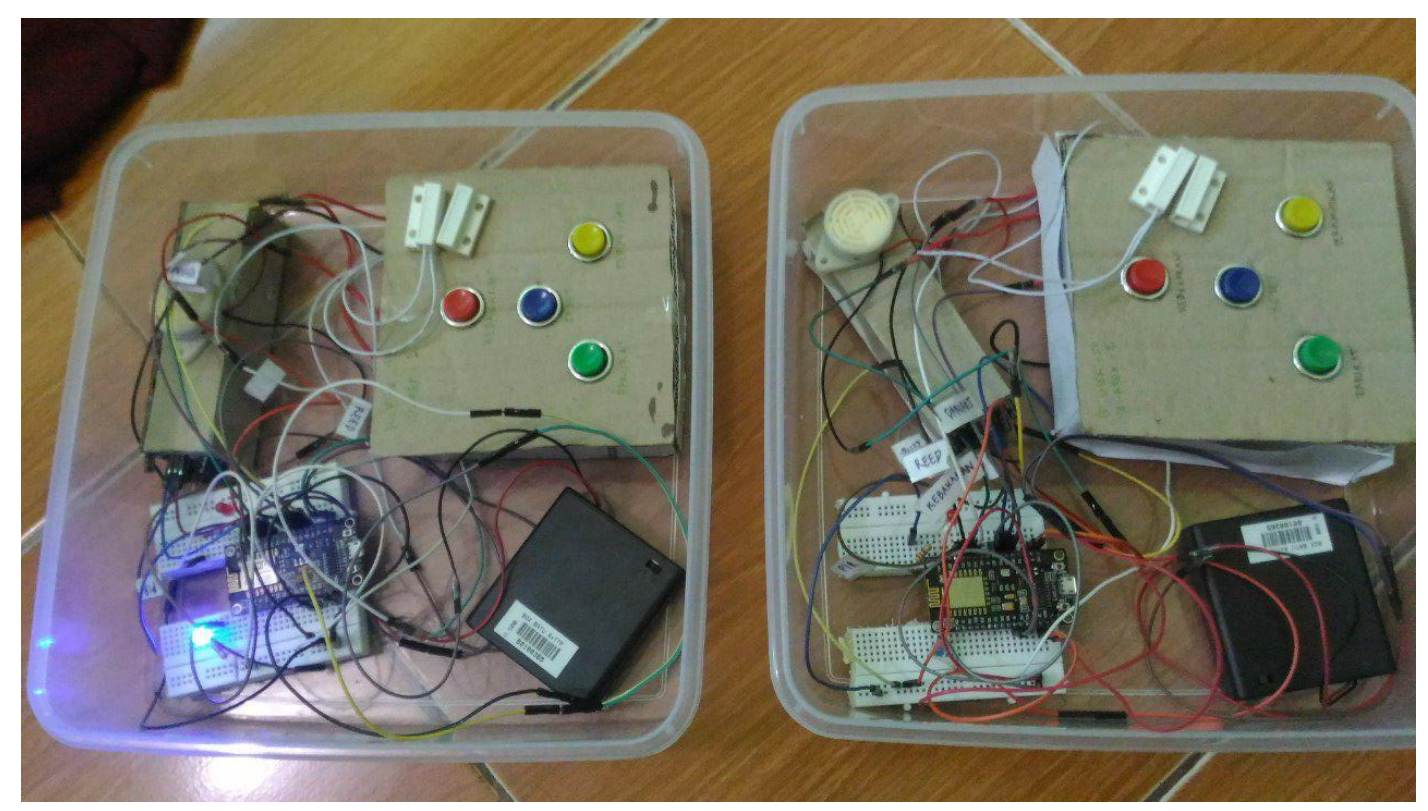

Gambar 10. Rangkaian Alat yang sudah jadi

Pada Gambar 11 terlihat bahwa pada alat 2 LED merah menyala menandakan bahwa sensor mendeteksi atau "panic button" ditekan. Sedangkan pada alat 1 LED merah tidak menyala. Hal ini dikarenakan antara alat 1 dan 2 berbeda kode area. Walaupun data tetap dikirimkan ke MQTTBroker oleh alat 2, namun alat 1 tetap tidak akan merespon.

Pada Gambar 12 terlihat bahwa LED merah pada alat 1 dan 2 menyala. Hal ini dikarenakan kode area kedua alat sama. Sehingga pada saat sensor mendeteksi atau tombol ditekan pada salah satu alat, alat yang memiliki kode area sama akan merespon, yaitu dengan menyalakan LED merah dan buzzer.

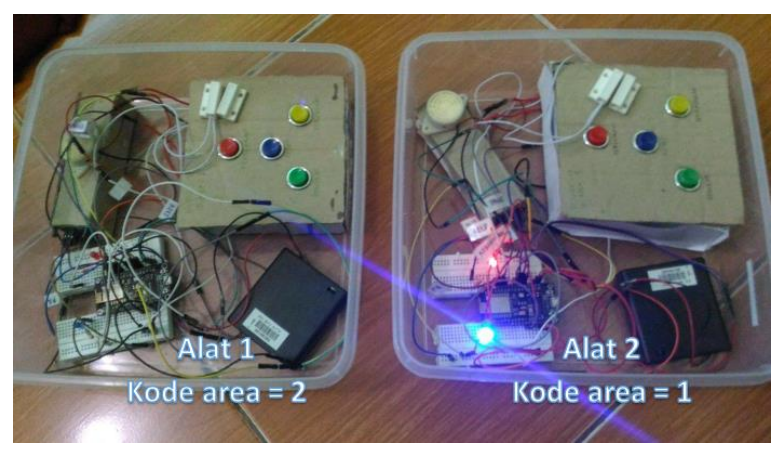

Gambar 11. Kode area pada alat berbeda

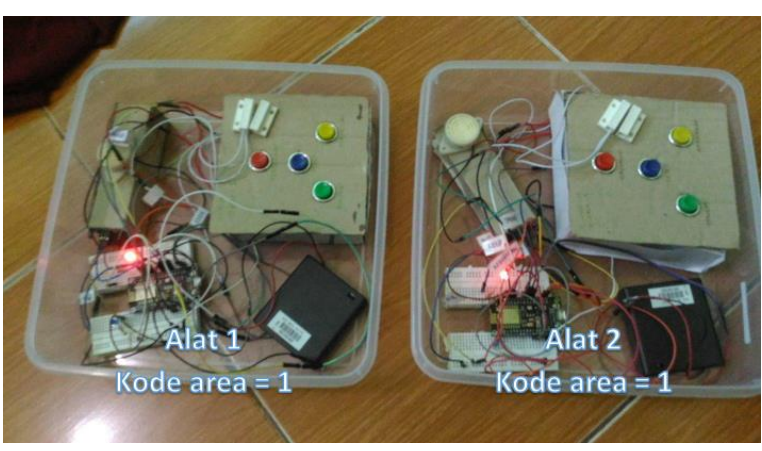

Gambar 12. Kode area pada alat sama

\subsection{Implementai Perangkat Lunak (Aplikasi)}

Pada halaman login, pengguna diminta untuk memasukkan username dan password yang telah dibuat sebelumnya. Tampilan halaman login dapat dilihat pada Gambar 13. Halaman My Home-Aman menampilkan gambar rumah berwarna hijau dan terdapat teks bertuliskan "Aman" yang menandakan keadaan dalam kondisi Aman atau tidak ada peringatan yang masuk. Tampilan halaman My Home-Aman dapat dilihat pada Gambar 14. 


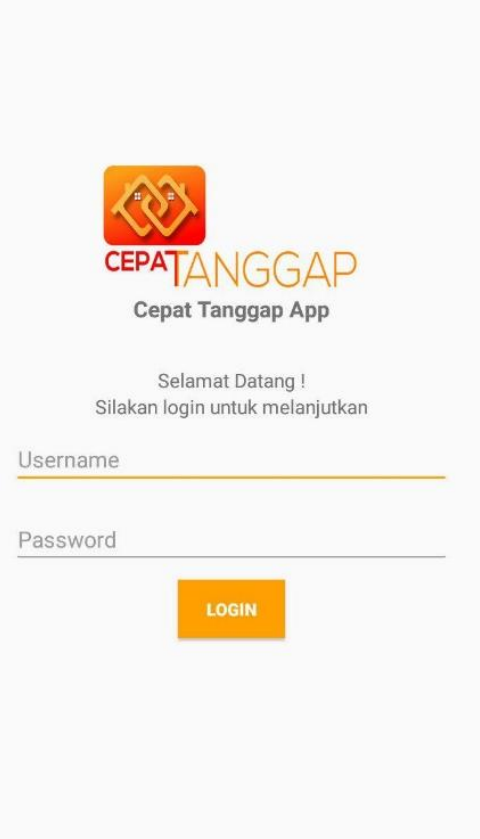

Gambar 13. Tampilan halaman login

\section{My Home}

My Home

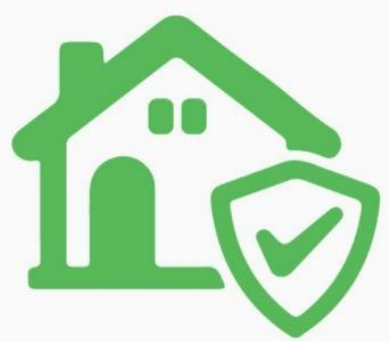

Aman

Halaman Terjadi Pergerakan menampilkan gambar rumah berwarna kuning dan terdapat teks "Terjadi Pergerakan" yang menandakan bahwa alat mendeteksi adanya pergerakan. Di halaman ini juga terdapat tombol "Aman". Tombol ini berfungsi untuk mengkonfirmasi keadaan apakah sudah aman atau belum. Apabila tombol "Aman" dipilih maka tampilan akan kembali ke halaman My Home-Aman. Jika user login sebagai petugas, maka akan muncul tombol "Buka Peta". Tombol ini berfungsi untuk melihat lokasi tempat kejadian pada aplikasi Maps atau Browser. Tampilan halaman Terjadi Pergerakan dapat dilihat pada Gambar 15.

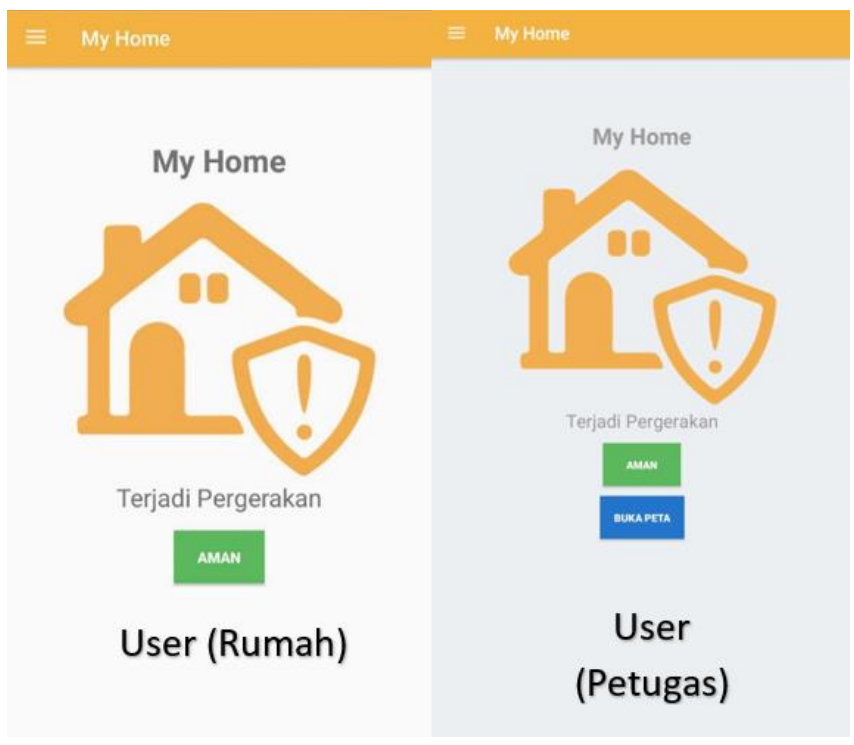

Gambar 15. Tampilan halaman Terjadi Pergerakan

Pada halaman Pintu Terbobol, Kebakaran, Perampokan, dan Darurat menampilkan gambar rumah berwarna merah dan terdapat teks sesuai dengan kondisi yang menandakan bahwa alat mendeteksi atau tombol pada alat ditekan. Di halaman ini juga terdapat tombol "Aman". Tombol ini berfungsi untuk mengkonfirmasi keadaan apakah sudah aman atau belum. Apabila tombol "Aman" dipilih maka tampilan akan kembali ke halaman My Home-Aman. Jika user login sebagai petugas, maka akan muncul tombol "Buka Peta". Tombol ini berfungsi untuk melihat lokasi tempat kejadian pada aplikasi Maps atau Browser. Tampilan halaman Pintu Terbobol, Kebakaran, Perampokan, dan Darurat dapat dilihat pada Gambar 16. 


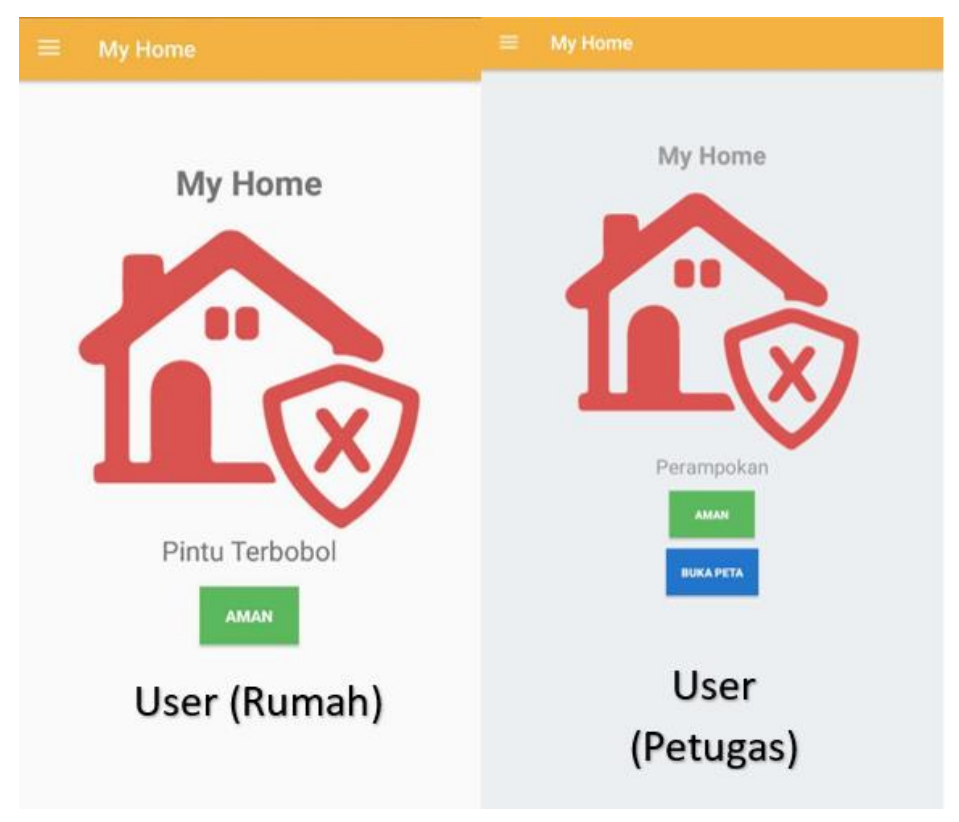

Gambar 16. Tampilan halaman Pintu Terbobol

Halaman Standby Switch berfungsi untuk melakukan controlling pada alat. Jika memilih "ON" maka sensor dan tombol akan aktif (bekerja), jika memilih "OFF" maka sensor dan tombol akan mati (tidak bekerja). Tampilan halaman Standby Switch dapat dilihat pada Gambar 17. Halaman History berfungsi untuk melihat riwayat peringatan yang pernah dikirimkan oleh alat. Tampilan halaman History dapat dilihat pada Gambar 18.
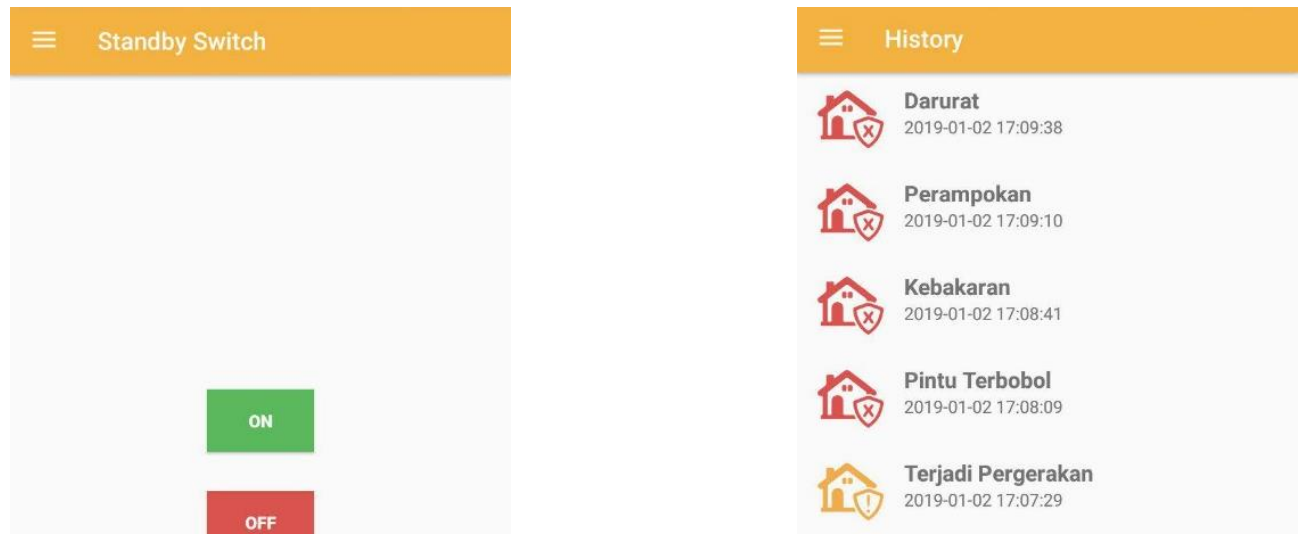

Gambar 17. Tampilan halaman Standby Switch

Gambar 18. Tampilan halaman History

\section{KESIMPULAN}

Dari penelitian yang telah dilakukan dapat diambil kesimpulan bahwa dalam pembuatan aplikasi android dan alat pengamanan rumah yang menggunakan board NodeMCU ESP8266 sebagai pusat kontrol dan menerapan konsep Internet of Things (IOT) telah berhasil dilakukan. Antara alat dan aplikasi android telah diimplementasikan dan dapat berjalan dengan baik. 
Alat ini mempunyai fungsi utama yaitu sebagai sistem keamanan rumah berbasis sensor dan tombol "panic button". Sedangkan aplikasi android memiliki fungsi sebagai alat monitor dan controlling terhadap alat. Dengan adanya alat dan aplikasi android yang saling terhubung, pengguna dimudahkan dalam mengawasi rumah walaupun rumah dalam keadaan kosong.

\section{DAFTAR PUSTAKA}

[1] N. Majumdar, P. Bhargava and R. K. Shirin, "Emergency Panic Button using Microcontrollers," International Journal of Computer Applications, pp. 1-3, 2014.

[2] A. A. I, O. Moses, M. O. S. B.-0. A. A. and A.-Z. T. P., "Design and Construction of A Panic Button Alarm System for Security Emergencies," International Journal of Engineering and Techniques , pp. 649-652, 2018.

[3] Febriansyah, Z. Zainuddin and M. B. Nappu, "Voice Based City Panic Button System," in The 2nd International Conference on Science (ICOS), 2018.

[4] D. H. Widhana, https://tirto.id/rampok-spesialis-rumah-kosong-di-jakarta-dkn6, terbit pada 28 Maret 2019, diakses pada 01 April 2019

[5] Subdirektorat Statistik Politik dan Keamanan, 2018, 'Statistik Kriminal 2018', Badan Pusat Statistik.

[6] J Tulle, Christian, D.N., 2017, Monitoring Volume Cairan dalam Tabung (Drum Silinder) dengan Sensor Ultrasonik berbasis Web, diploma thesis, STMIK AKAKOM Yogyakarta.

[7] Triwahida, A., 2000, 'Sistem Pengaman Rumah Dengan Sensor Pir (Passive Infrared) Berbasis Mikrokontroler ATmega 8535', skripsi, Universitas Gunadarma.

[8] Heranudin, 2008, 'Rancang Bangun Sistem Keamanan Ruangan Menggunakan Radio Frequency Identifikasi (RFID) Berbasis Mikrokontroler AT89C51', skripsi, Universitas Indonesia. 